\title{
ENEA RADIOCARBON MEASUREMENTS III
}

\author{
Giuseppe Magnani ${ }^{1} \bullet$ Paolo Bartolomei • Teresa La Torretta • Ernesto Claudio Marino \\ ENEA, Radiocarbon Laboratory, Via dei Colli, 16, 40136 Bologna, Italy.
}

ABSTRACT. This paper includes determinations of archaeological samples coming from different sites and performed at the ENEA Radiocarbon Laboratory.

\section{INTRODUCTION}

In this report, we present the dating results of archaeological samples processed at the ENEA Radiocarbon Laboratory, Bologna, Italy. Most of the samples reported in the list are related to excavations carried out by researchers at the University of Bologna, Department of Archaeology.

Samples of shells and charcoals were treated following the method reported by Magnani et al. (2006, 2007). Age calculations are based on Libby half-life of $5568 \mathrm{yr}$ and are expressed in ${ }^{14} \mathrm{C} \mathrm{yr}$ relative to AD 1950 as the reference year. Ages and standard deviations (1- $\sigma$ error) of samples are adjusted for stable isotope fractionation to a normalized concentration ratio $\left(\delta^{13} \mathrm{C}=-25 \%\right.$ ) according to the recommendations reported by Stuiver and Polach (1977), using the default $\delta^{13} \mathrm{C}$ values.

Calibrated ages are calculated from rounded ${ }^{14} \mathrm{C}$ conventional ages utilizing the program OxCal v 3.10 (Bronk Ramsey 1995, 2001, 2005) with 1- $\sigma$ error (confidence level 68.2\%) and using the IntCal04 calibration curve data (Reimer et al. 2004). When several calendar age ranges are obtained, the probability for each interval is given. Probabilities $<5 \%$ are omitted.

\section{PAKISTAN}

Samples from the Bir-Kot-Ghwandai excavation (Swat Valley, $36^{\circ} 33^{\prime} \mathrm{N}, 7^{\circ} 02^{\prime} \mathrm{E}$ ) (Figure 1) in Pakistan were collected in 1987-1990 and submitted from 1988 to 1991 by P Callieri, Department of Archaeology, University of Bologna, Italy.

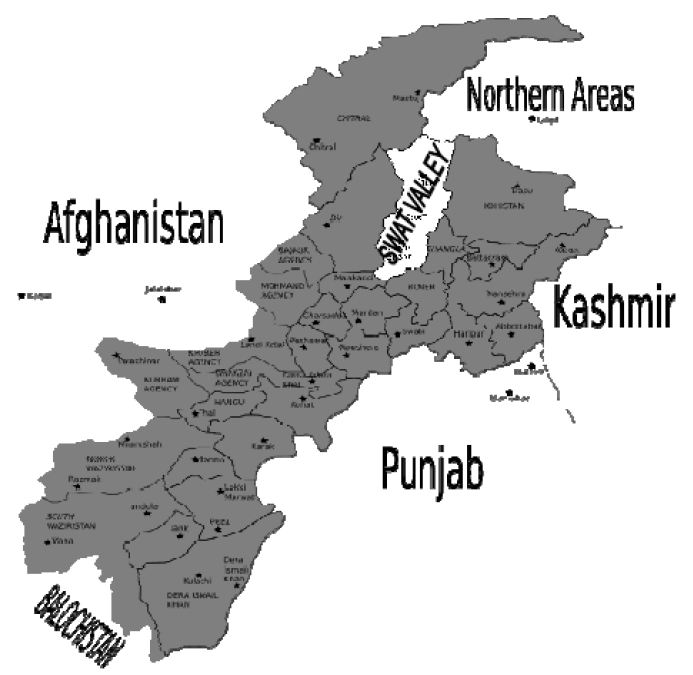

Figure 1 Map of Swat Valley sampling site

${ }^{1}$ Corresponding author. Email: giuseppe.magnani@bologna.enea.it. 
ENEA-181. BKG 310 US 592

$2100 \pm 60$

Charcoal (200-40 cal BC, 68.2\%).

$2040 \pm 100$

ENEA-182. BKG 302 US 449

$1180 \pm 60$

ENEA-183. BKG 2 US 344

$1160 \pm 50$

ENEA-184. BKG 215 US 365

$1160 \pm 50$

Charcoal (cal AD 780-900, 47.7\%; AD 910-960, 20.5\%).

ENEA-185. BKG 215 US 317

$620 \pm 50$

Charcoal (cal AD 1300-1330, 27.1\%; AD 1340-1400, 41.1\%).

Comment: The historic settlement of Bir-Kot-Ghwandai is comprised of a small hill situated on an east-west axis, rising on the left bank of the River Swat to the west of the modern village. The samples were found during the BKG2 excavation campaign carried out in the area, which gathered a fair amount of pottery. The ages reported here were compared with dating results from the nearby site of Damkot, thus allowing us to assign the pottery to the Hindu Shahis period (9th-11th centuries AD). These dates were first published by Callieri et al. (1992).

\section{LYBIA}

Samples from the Uan Tabu excavation were located on the left bank of the central valley of the Wadi Teshuinat. This wadi is the main ancient water course in the central Tadrart Acasus mountain range, in the Frezzan region of southwestern Libya $\left(24^{\circ} 51^{\prime} 35^{\prime \prime} \mathrm{N}, 10^{\circ} 31^{\prime} 42^{\prime \prime} \mathrm{E}\right)$. Samples were collected in 1990-1993 and submitted in 1990-1999 by E A A Garcea, Department of Philology and History, University of Cassino, Italy.

ENEA-191. TB1-A I

$8720 \pm 110$

Charcoal, 15 cm depth (7950-7600 cal BC, 68.2\%).

ENEA-192. TB1-D II

$8640 \pm 70$

Charcoal, 25 cm depth (7740-7580 cal BC, 68.2\%).

ENEA-193. TB1-D IV

$8690 \pm 60$

Charcoal, $50 \mathrm{~cm}$ depth (7780-7590 cal BC, 68.2\%).

ENEA-340. TB1-A

$3810 \pm 100$

Charcoal, $1.0 \mathrm{~m}$ above surface (2460-2420 cal BC, 6.1\%, 2410-2130 cal BC, 60.5\%).

ENEA-344. TB1-A $S$

$8580 \pm 90$

Wood collected on the surface of the excavation (7740-7530 cal BC, 68.2\%).

ENEA-478. TB1-A IX

$8730 \pm 70$

Charcoal, $90 \mathrm{~cm}$ depth (7840-7600 cal BC, 64.1\%).

ENEA-508. Uan Tabu 1A-17

$9350 \pm 70$

Charcoal, $1.5 \mathrm{~m}$ depth (8740-8530 cal BC, 63.3\%).

ENEA-509. Uan Tabu 1A-20

$9810 \pm 80$

Charcoal, 1.9 m depth (9350-9200 cal BC, 65.8\%).

ENEA-565. Uan Tabu 2A-20

$9450 \pm 60$

Charcoal, 2.0 m depth (8740-8530 cal BC, 63.3\%). 
ENEA-606. Uan Tabu L3UL-2A

$8600 \pm 80$

Charcoal, $40 \mathrm{~cm}$ depth (7720-7550 cal BC, 68.2\%).

ENEA-607. Uan Tabu L7UL-1D

$8830 \pm 75$

Charcoal, $70 \mathrm{~cm}$ depth (8200-8030 cal BC, $29.2 \%$; 8010-7810 cal BC, 39.0\%).

ENEA-608. Uan Tabu 1A-9

$8770 \pm 75$

Charcoal, $90 \mathrm{~cm}$ depth (7960-7650 cal BC, 68.2\%).

ENEA-609. Uan Tabu 1A-13

$8820 \pm 80$

Charcoal, $1.1 \mathrm{~m}$ depth (8190-8110 cal BC, $13.1 \%$; 8000-7750 cal BC, 49.5\%).

Comment: This excavation was aimed at updating the available data through a wide range of interdisciplinary studies, reconstructing the cultural sequence of the anthropic deposit and relating it to the rock paintings present in the shelter and to the general environmental context. Based on the ages reported here, the entire deposit appears to be earlier than the date of $7045 \pm 175 \mathrm{BP}$ obtained in the 1960s from the 1960-1963 trench (Mori 1965). In fact, the Holocene layers ranged between 9810 and $8580 \mathrm{BP}$. The date of $3810 \pm 100 \mathrm{BP}$ came from dung preserved in a niche in the wall of the shelter located about $1 \mathrm{~m}$ above the present surface. Such a date must refer to a much later use of the site, following its systematic occupation. All other ${ }^{14} \mathrm{C}$ dates agree with the prepastoral horizons. These results were published in Bartolomei and Rizzo (2001).

\section{OMAN}

An Italian archaeological mission in the Sultanate of Oman started in 1985, supported by the Joint Hadd Project formed by the Instituto Italiano per l'Asia e l'Oriente (IsIAO, Italy), the Maison de l'Archéologie et de l'Ethnologie (CNRS, France), and the universities of Bologna and Trento. Several archaeological sites were identified in the eastern province of the Sultanate of Oman and their locations are reported in Figure 2.

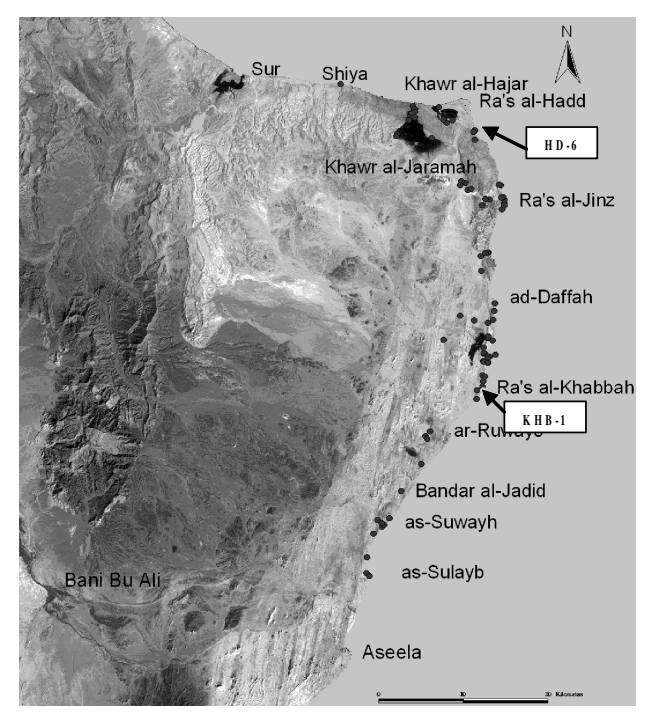

Figure 2 Map of the eastern province of the Sultanate of Oman with the location of the HD-6 and KHB-1 archaeological sites indicated. 


\section{Ra's al-Hadd Series}

These charcoal samples came from the HD-6 excavation $\left(22^{\circ} 13^{\prime} 30^{\prime \prime} \mathrm{N}, 59^{\circ} 31^{\prime} 42^{\prime \prime} \mathrm{E}\right)$ located near the coastal village of Ra's al-Hadd (Figure 2). Samples were collected and submitted in 1999 by M Tosi, Department of Archaeology, University of Bologna, Italy. Ages were calibrated using the marine curve Marine04 (Hughen et al. 2004), applying a reservoir effect correction ( $\Delta \mathrm{R})$ of $200 \pm 60 \mathrm{yr}$ (Southon et al. 2002).

ENEA-515. I-J-101 US19

$3840 \pm 130$

Charcoal (2470-2130 cal BC, 65.0\%).

ENEA-516. K101-US22

$3570 \pm 180$

Charcoal (2200-1650 cal BC, 68.2\%).

ENEA-517. G-H 100-101 US7

$2250 \pm 270$

Charcoal (800 cal BC-cal AD 50, 68.2\%).

ENEA-597. HD6 N101 US314

$7150 \pm 400$

Charcoal (6450-5600 cal BC, 68.2\%).

ENEA-598. HD6 256

$5100 \pm 1000$

Charcoal (5000-2600 cal BC, 68.2\%).

Comment: HD6, a settlement site located on the eastern beach, revealed a rich archaeological context containing an abundance of copper hooks, beads, and bone as well as the remains of small, round buildings. This site shows a significant assemblage of environmental evidence, which should do much to increase archaeological understanding of the lives of the early occupants.

\section{Ra's al-Khabbah Series}

Shell samples came from the uppermost stratigraphic layers of the KHB-1 excavation $\left(22^{\circ} 13^{\prime} 30^{\prime \prime} \mathrm{N}\right.$, $\left.59^{\circ} 31^{\prime} 42^{\prime \prime} \mathrm{E}\right), 1.5 \mathrm{~km}$ north of the village of Khabbah and $<1 \mathrm{~km}$ from the Ra's al-Khabbah headland in the Ja'lan region, the eastern province of the Sultanate of Oman (see Figure 2). The samples were collected and submitted in 2000 by F Cavulli, Department of Archaeology, University of Bologna, Italy. Ages were calibrated using the marine curve Marine04 (Hughen et al. 2004), applying a reservoir effect correction $(\Delta \mathrm{R})$ of $200 \pm 60 \mathrm{yr}$ (Southon et al. 2002).

ENEA-635. KHB-1 US59 str.A

$4920 \pm 80$

Anadara shell sample (3170-2870 cal BC, 68.2\%).

ENEA-648. KHB-1 Surface 1

$5610 \pm 280$

Anadara shell sample (4200-3500 cal BC, 68.2\%).

ENEA-655. KHB-1 US105

$4850 \pm 80$

Anadara shell sample (3090-2820 cal BC, 65.3\%).

ENEA-658. KHB-1 Amiantis Anadara

$5120 \pm 120$

Anadara shell sample (3450-3090 cal BC, 68.2\%).

ENEA-683. KHB-1 US104

$4810 \pm 60$

Anadara shell sample (3000-2760 cal BC, 68.2\%).

ENEA-688. KHB-1 US220

$4610 \pm 50$

Anadara shell sample (2730-2480 cal BC, 68.2\%). 
ENEA-690. KHB-1 US145

$4870 \pm 50$

Anadara shell sample (3050-2860 cal BC, 68.2\%).

ENEA-691. KHB-1 US108

$4860 \pm 50$

Anadara shell sample (3030-2850 cal BC, 68.2\%).

ENEA-737. KHB-1 US1 E102

$4890 \pm 50$

Anadara shell sample (3070-2870 cal BC, 68.2\%).

Comment: The results place the uppermost stratigraphic layers of KHB-1 from the end of the 4th millennium $\mathrm{BC}$ to the beginning of the $3 \mathrm{rd}$ millennium $\mathrm{BC}$, in agreement with previous ${ }^{14} \mathrm{C}$ determinations of the same site and the same stratigraphic layer (Biagi 1994). These results were published in Magnani et al. (2007).

\section{TUNISIA}

The shell samples came from the SHM-1 excavation, $5 \mathrm{~km}$ south of the village Hergla in the coastal lagoon Sebkhet Halk el Menzel (Sousse region, 36 $00^{\circ} 61^{\prime \prime} \mathrm{N} ; 10^{\circ} 27^{\prime} 49^{\prime \prime} \mathrm{E}$; see Figure 3). They were collected and submitted in 2002 and 2007 by S Mulazzani, Department of Archaeology, University of Bologna, Italy. Ages were calibrated using the marine curve Marine04 (Hughen et al. 2004), applying a reservoir effect correction $(\Delta \mathrm{R})$ of $58 \pm 85 \mathrm{yr}$ (Reimer et al. 2002).

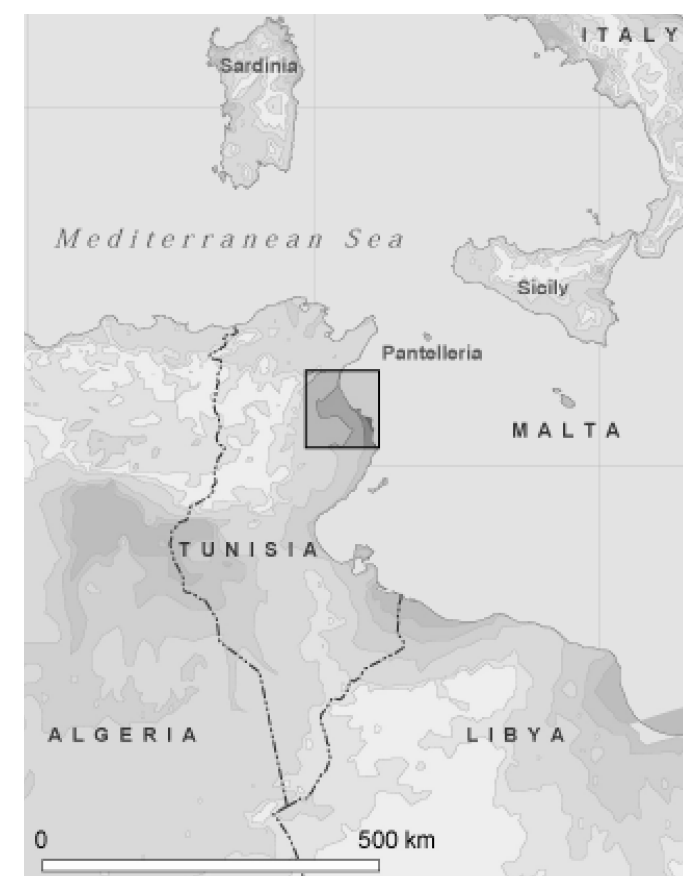

Figure 3 Map of the Tunisian sampling area

ENEA-659. US 214 DM 41-42

$7420 \pm 40$

Cerastoderma glaucum shell sample, $30 \mathrm{~cm}$ depth (5980-5780 cal BC, 68.2\%).

ENEA-663. US 215 DM 39-40

$8170 \pm 130$

C. glaucum shell sample, $50 \mathrm{~cm}$ depth (6850-6450 cal BC, 67.4\%). 
ENEA-664. US 213 DM 45-46 TETTO

$7270 \pm 260$

C. glaucum shell sample, $20 \mathrm{~cm}$ depth (6000-5450 cal BC, $68.2 \%)$.

ENEA-665. US 12

$6970 \pm 140$

C. glaucum shell sample, $30 \mathrm{~cm}$ depth (5620-5310 cal BC, 68.2\%).

ENEA-666. US 13 TETTO

$6990 \pm 80$

C. glaucum shell sample, $40 \mathrm{~cm}$ depth (5600-5380 cal BC, 68.2\%).

ENEA-667. US 13 BASE

$6990 \pm 80$

C. glaucum shell sample, $40 \mathrm{~cm}$ depth (5600-5380 cal BC, $68.2 \%)$.

ENEA-668. US 217

$7200 \pm 60$

C. glaucum shell sample, $40 \mathrm{~cm}$ depth (5770-5560 cal BC, 68.2\%).

ENEA-835. US 305 SG5

$7160 \pm 40$

C. glaucum shell sample, $40 \mathrm{~cm}$ depth (5720-5540 cal BC, $68.2 \%)$.

ENEA-836. US 350 SG5

$7520 \pm 40$

C. glaucum shell sample, $40 \mathrm{~cm}$ depth (6070-5860 cal BC, 68.2\%).

ENEA-837. US 481B SG5

$7920 \pm 40$

C. glaucum shell sample, $40 \mathrm{~cm}$ depth (6460-6260 cal BC, 68.2\%).

ENEA-838. US 440 SG5

$7200 \pm 40$

C. glaucum shell sample, $40 \mathrm{~cm}$ depth (5760-5570 cal BC, 68.2\%).

ENEA-839. US 410 SG5

$7330 \pm 40$

C. glaucum shell sample, $40 \mathrm{~cm}$ depth (5890-5690 cal BC, 68.2\%).

ENEA-840. US 515 SG5

$7870 \pm 30$

C. glaucum shell sample, $40 \mathrm{~cm}$ depth (6420-6230 cal BC, 68.2\%).

ENEA-841. US 529 SG5

$7870 \pm 30$

C. glaucum shell sample, $40 \mathrm{~cm}$ depth (6420-6230 cal BC, 68.2\%).

Comment: These ages confirmed that the SHM-1 site was occupied during 7th-6th century BC.

PERU

Samples came from different sites of an excavation located in the Chacas Valley (Ancash region, $9^{\circ} 15^{\prime} 1^{\prime \prime} \mathrm{S}, 77^{\circ} 22^{\prime} 51^{\prime \prime} \mathrm{W}$ ) of Peru. They were collected in 2002 and submitted in 2003 by C Orsini, Department of Paleografia and Medievistica, University of Bologna, Italy. Ages were calibrated using the Southern Hemisphere curve SHCal04 (McCormac et al. 2004).

ENEA-702. BOLSA 64C

$540 \pm 230$

Charcoal from the Jatungaga Pirusthu site (CVP25), $10 \mathrm{~cm}$ depth (cal AD 1260-1660, 68.2\%).

ENEA-703. BOLSA 23A

$2160 \pm 60$

Charcoal from the Chagastunan site (CVP13), $20 \mathrm{~cm}$ depth (210-40 cal BC, 66.8\%).

ENEA-705. BOLSA 60C

$790 \pm 55$

Charcoal from the Jatungaga Pirusthu site, surface (cal AD 1220-1300, 68.2\%).

ENEA-701. BOLSA 68

$2060 \pm 110$

Soil from the Jatungaga Pirusthu site, $1.0 \mathrm{~m}$ depth (cal 170 BC-AD 90, 64.3\%). 
ENEA-706. BOLSA 5

Charcoal from the Balcon de Judas site (CVP30), $20 \mathrm{~cm}$ depth (510-430 cal BC; 7.4\%, 420-160 cal BC, 60.8\%).

Comment: The ages reported here contributed to the comprehension of the pre-Columbian cultures of the Chacas Valley.

\section{CONCLUSION}

The ENEA Radiocarbon Laboratory participated in the study of archaeological excavations in collaboration with different partners. Several age determinations were made in order to acquire additional information on the development of ancient cultures.

\section{REFERENCES}

Bartolomei P, Rizzo A. 2001. Radiocarbon dates of charcoal samples from the Holocene sequence. In: Garcea EAA, editor. Uan Tabu: In the Settlement History of the Libyan Sahara. Florence: Edizioni all'Insegna del Giglio. p 63-8.

Biagi P. 1994. A radiocarbon chronology for the aceramic shell-middens of coastal Oman. Arabian Archaeology and Epigraphy 5(1):17-31.

Bronk Ramsey C. 1995. Radiocarbon calibration and analysis of stratigraphy: the OxCal program. Radiocarbon 37(2):425-30.

Bronk Ramsey C. 2001. Development of the radiocarbon calibration program OxCal. Radiocarbon 43(2A): 355-63.

Bronk Ramsey C. 2005. The OxCal program manual v 3.10 [WWW document]. The Oxford Radiocarbon Accelerator Unit, University of Oxford. URL: http:// www.rlaha.ox.ac.uk/oxcal/oxcal.htm.

Callieri P, Brocato P, Filigenzi A, Nascari M, Olivieri LM. 1992. Bir-Kot-Ghwandai 1990-1992. A preliminary report on the excavations of the Italian Archaeological Mission, IsMEO. Annali dell'Instituto Universitario Orientale di Napoli 52(4):1-48.

Hughen KA, Baillie MGL, Bard E, Bayliss A, Beck JW, Bertrand CJH, Blackwell PG, Buck CE, Burr GS, Cutler KB, Damon PE, Edwards RL, Fairbanks RG, Friedrich M, Guilderson TP, Kromer B, McCormac G, Manning S, Bronk Ramsey C, Reimer PJ, Reimer RW, Remmele S, Southon JR, Stuiver M, Talamo S, Taylor FW, van der Plicht J, Weyhenmeyer CE. 2004. Marine04 marine radiocarbon age calibration, 0-26 cal kyr BP. Radiocarbon 46(3):1059-86.

Magnani G, Bartolomei P, La Torretta T, Marino EC, Go- voni C. 2006. ENEA radiocarbon measurements I. Radiocarbon 48(1):167-75.

Magnani G, Bartolomei P, Cavulli F, Esposito M, Marino EC, Neri M, Rizzo A, Scaruffi S, Tosi M. 2007. U-series and radiocarbon dates on mollusc shells from the uppermost layer of the archaeological site of KHB-1, Ra's al Khabbah, Oman. Journal of Archaeological Science 34(5):749-55.

McCormac FG, Hogg AG, Blackwell PG, Buck CE, Higham TFG, Reimer PJ. 2004. SHCal04 Southern Hemisphere calibration, 0-11.0 cal kyr BP. Radiocarbon 46(3):1087-92.

Mori F. 1965. Tadrart Acasus. Arte Rupestre e Culture del Sahara Preistorico. Torino: Einaudi. In Italian.

Reimer PJ, McCormac FG. 2002. Marine radiocarbon reservoir corrections for the Mediterranean and Aegean seas. Radiocarbon 44(1):159-66.

Reimer PJ, Baillie MGL, Bard E, Bayliss A, Beck JW, Bertrand CJH, Blackwell PG, Buck CE, Burr GS, Cutler KB, Damon PE, Edwards RL, Fairbanks RG, Friedrich M, Guilderson TP, Hogg AG, Hughen KA, Kromer B, McCormac G, Manning S, Bronk Ramsey C, Reimer RW, Remmele S, Southon JR, Stuiver M, Talamo S, Taylor FW, van der Plicht J, Weyhenmeyer CE. 2004. IntCal04 terrestrial radiocarbon age calibration, 0-26 cal kyr BP. Radiocarbon 46(3):1029-58.

Southon J, Kashgarian M, Fontugne M, Metivier B, Yim WW-S. 2002. Marine reservoir corrections for the Indian Ocean and Southeast Asia. Radiocarbon 44(1): 167-80.

Stuiver M, Polach HA. 1977. Discussion: reporting of ${ }^{14} \mathrm{C}$ data. Radiocarbon 19(3):355-63. 